\title{
Heterozygous Beta-thalassemia, a Genetic Haemolytic Anaemia in Continuous Expansion
}

\author{
Șeicaru D11, Constantinescu Dorina², Frecus Corina3 ${ }^{3}$ Bulucea D4 \\ 1 Family medicine physician, University of Medicine and Pharmacy, Craiova, Romania \\ 2 Department of Pediatrics, County Emergency Hospital Râmnicu Vâlcea, University of Medicine and Pharmacy, Craiova, Romania \\ 3 Department of Pediatrics, University of Medicine and Pharmacy, Constanța, Romania \\ 4 University of Medicine and Pharmacy, Craiova, Romania
}

\begin{abstract}
Introduction: Heterozygous $\beta$-thalassemia represents the mild form of the $\beta$-thalassemic syndromes, being compatible with normal lifetime. The importance of $\beta$-thalassemia consists in the fact that it maintains the "defective gene" in the population, favoring the appearance of new cases of Cooley's anaemia, the severe form of $\beta$-thalassemic syndromes. Current data estimate that $7 \%$ of the world's population is bearing $\beta$-thalassemia, over 400,000 children with $\beta$-thalassemia being born annually, therefore the WHO estimates the doubling of this figure in the coming years.

Material and methods: We carried out a retrospective clinical study of over 450 cases diagnosed with $\beta$-thalassemia in the Dolj, Constanța and Vâlcea counties, along a period of 10 years (2001-2010), out of which we analyzed the family tree of 10 cases throughout 3-4 generations, starting from the cases of children diagnosed with $\beta$-thalassemia.

Results: The number of heterozygous subjects that emerged over 3-4 generations was of 60 cases with $\beta$-thalassemia and 9 cases with Cooley's anaemia. Thus, starting from the 10 cases of $\beta$-thalassemic married subjects (great grandfathers/great grandmothers, grandfathers/ grandmothers) along 3-4 generations (over a period of 70-80 years) the number of new $\beta$-thalassemia cases was 5.4 times higher.

Conclusions: According to our results, the last generation of the studied children and adolescents shows the presence of a total of 18 subjects with $\beta$-thalassemia, suggesting the increasing amount of heterozygotes in the population.
\end{abstract}

Keywords: heterozygous $\beta$-thalassemia, family tree, diagnosis, prevention of disease, genetic counseling

Received: 17 April 2012

\section{Introduction}

Heterozygous $\beta$-thalassemia ( $\beta$-th) represents the mild form of the $\beta$-thalassemic syndromes, being compatible with normal lifetime. The importance of $\beta$-th consists in the fact that it maintains the "defective gene" in the population, favoring the appearance of new cases of Cooley's anaemia, the severe form of $\beta$-thalassemic syndromes. Current data estimate that $7 \%$ of the world's population is bearing the $\beta$-th, over 400,000 children with $\beta$-th being born annually, therefore the WHO estimates the doubling of this figure in the coming years.

\section{Material and methods}

We carried out a retrospective clinical study of over 450 cases diagnosed with $\beta$-th in the Dolj, Constanța and Vâlcea counties, along a period of 10 years (2001-2010), out of which we analyzed the family tree of 10 cases throughout 3-4 generations, starting from the cases of children diagnosed with $\beta$-th.

\section{Results}

Out of the 10 families analysed with the objective to determine the number of cases with $\beta$-thalassemic syndromes, 9 married couples consisted of a heterozygous subject and

Correspondence to: Doru Seicaru

E-mail: adiseicaru@yahoo.com a normal one, and only one couple was formed of two heterozygous subjects.

The number of heterozygous subjects that emerged over 3-4 generations was 60 cases with $\beta$-th and 9 cases with Cooley's anaemia.

Thus, starting from 10 cases of $\beta$-thalassemic married subjects (great grandfathers/great grandmothers, grandfathers/grandmothers) along 3-4 generations (over a period of $70-80$ years) the number of new $\beta$-th cases was 5.4 times higher.

The 9 patients with Cooley's anaemia resulted from marriages between heterozygous subjects, a number of 3 couples (great grandparents, grandparents, adults).

Most couples have taken genetic counseling (marriage between a heterozygote and a normal subject).

In the youngest generation included in the study, 18 subjects had $\beta$-th.

\section{Discussions}

$\beta$-thalassemic syndromes are a diverse group of hereditary diseases within the larger background of anaemia, whose basic disorder consists of the partial or total blockage in the synthesis of one of the polypeptide catenae of globin, resulting in the decreased production of normal globin [1, $2,3,4,5,6,7,8]$.

$\beta$-thalassemic syndromes hold the first place in the world both in incidence and number of affected subjects, 


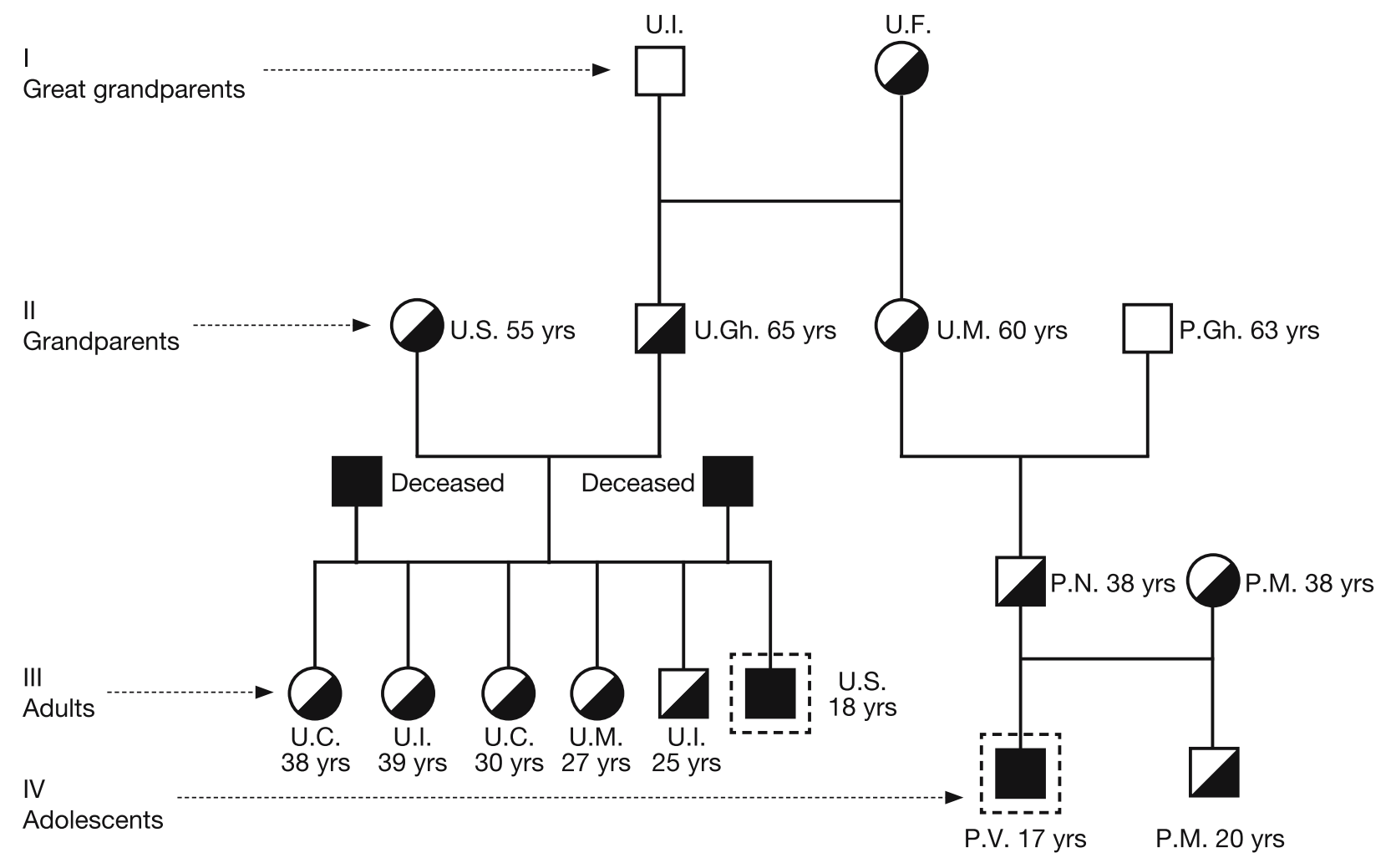

Fig. 1. Starting with the great grandparents and taking into account a heterozygous subject, in the following three generations within 4 families, we come to 11 subjects with $\beta$-th and 4 subjects with Cooley anemia. Following this epidemiological survey, we notice that the penetrance of the gene was aggressive, from 1 heterozygote coming to 11 cases with $\beta$-th, 4 cases with Cooley anemia (two of which are deceased). One can also notice the excessive reproduction (undesirable) resulting into the appearance of eight children, out of whom only one was normal, three were diagnosed with Cooley anemia and the rest were heterozygotes.

but also in gravity, through their major form, Cooley's anaemia $[5,6,7,9,10]$. Although these syndromes can be met on every continent, the area of maximum incidence surrounds the globe as a belt, from the Mediterranean, over the Middle East and India, till the Far East. The European countries with the highest incidence are Cyprus, Italy and Greece $[2,3]$.

Due to the fact that Romania is geographically close to these countries, as well as to the migration area of ancient populations, it is characterized by an average spread of thalassemia, especially in the south of the country, but there were also some cases identified in Banat, Transylvania and Moldavia [5,11].

Anaemia in $\beta$-thalassemic syndromes is the result of the interaction between two pathophysiological mechanisms - ineffective erythropoiesis and the shortened lifetime of erythrocytes. The major disorder in $\beta$-thalassemia is represented by the blockage of the synthesis of the $\beta$ chain of the globin, resulting in the excessive presence of partner chains which throw down as erythrocyte inclusions [2, $5,6,8,12]$.

Heterozygous $\beta$-thalassemia, the mildest form of $\beta$-thalassemic syndromes, by similarity to the hypochromic, hyposideremic anaemia (iron deficiency anaemia), is even today accidentally diagnosed in childhood or in other periods of life, including adults, when a haematological routine examination of peripheral blood reveals microcytic hypochromic anaemia with changes that attract attention, such as moderately low haemoglobin, moderate poliglobulia with decreased HEM, MCV erythrocyte indices and significant changes in the erythrocyte series on the blood smear ( hypochromia, microcytosis, anisocytosis, "on target" erythrocytes etc.) suggesting the suspicion of $\beta$-thalassemia $[7,8,10,13,14,15]$.

After the year 2000, at the University of Medicine and Pharmacy from Craiova, we have taken the initiative to begin a study in order to actively detect $\beta$-th in the Department of Pediatrics of the "Filantropia" City Hospital. Later on, the research has been expanded through doctoral work, both in Constanța and Vâlcea counties [14,15,16,17].

The result of this research was to highlight over 450 cases of $\beta$-th in children and adolescents as a starting point. These cases were diagnosed in the Pediatric Departments (Craiova, Constanta) and the Department of Pediatrics of the County Emergency Hospital of Râmnicu Vâlcea. If we were to compare the diagnosis of $\beta$-th cases in other Departments of Pediatrics in Craiova, note that the results are below expectations (only a few cases annually).

The method of work and of actively detecting the $\beta$-th cases were also presented in previous work $[13,15]$. 
I Great grandparents
I.A.

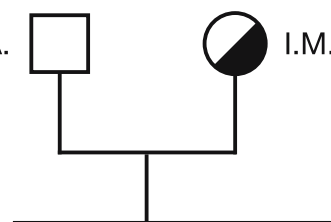

I.M.

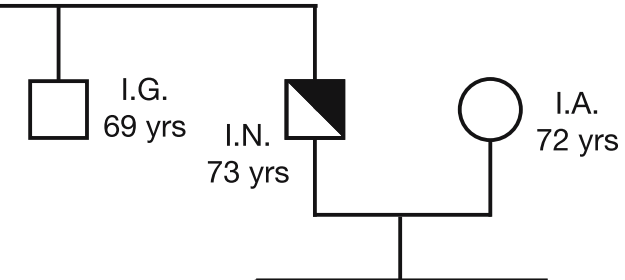

II Grandparents onds

III Adults Aduls

IV Children
F.T. F.I.

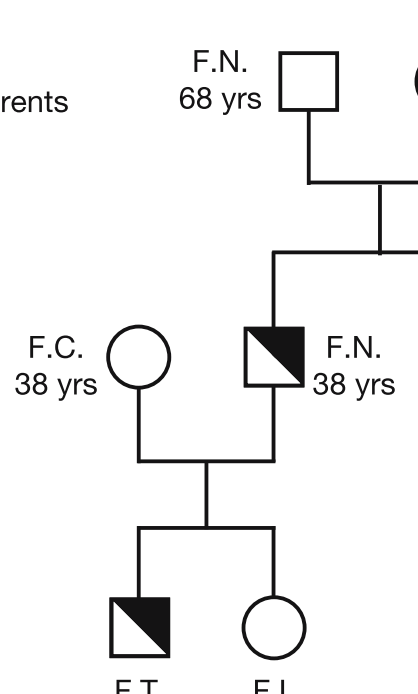

F.N. 68 yrs

2 yrs

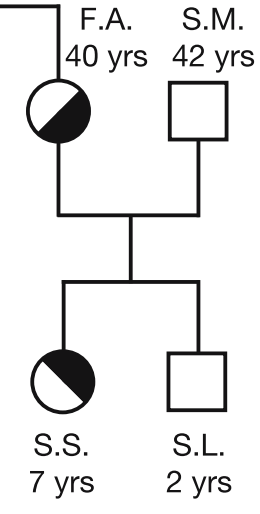

I.V.

69 yrs

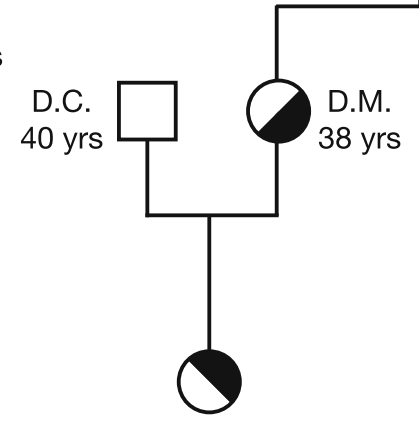

D.I.

2 yrs

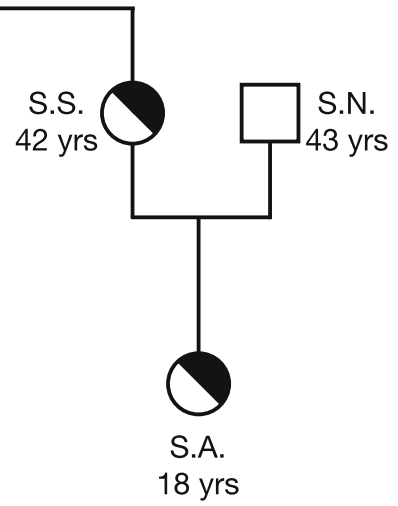

Fig. 2. Starting point - F.T., aged 6, a Romanian ethnic with $\beta$-th, from Constanța. After his being diagnosed, other three of his cousins (S.S. aged 6, D.I. aged 2 and S.A. aged 18) were diagnosed with $\beta$-th; his sister is not a carrier of the thalassemia tare. The epidemiological investigation covers a period of four generations.

This paper is aimed at making the medical world aware of the evolution towards permanent, global expanding of $\beta$-th, regardless of the complex preventive work based on genetic counselling.

This situation was mentioned by the WHO which estimated that $7 \%$ of the world's population is currently carrying $\beta$-th, and more than 400,000 new cases are annually diagnosed, claiming that these figures will double in the following years [18]. The present study demonstrated the accuracy of this data, discovering 60 cases of $\beta$-th and 9 cases of Cooley's anemia over 3-4 generations. It is also to be noted that out of the 40 marriages throughout these 3-4 generations, 33 couples (82\%) followed genetic counselling (marriage between a heterozygote and a normal subject), only 7 couples failing to take this advice or not knowing that both partners were heterozygote.

The present study also shows that out of the couples in which one partner was heterozygote, there were some cases where both conceived children were heterozygote; however, the most common situation consisted in a normal child and a heterozygote child. It is not desirable to have marriages in which both partners are heterozygote and do not know this thing. Therefore it is recommended to enable postpartum early detection of $\beta$-th in a newborn after six months of life, through the elements listed above, the suspicion of $\beta$-th being signalled by a moderate anaemia with poliglobulia and low erythrocytes indices, as well as by some changes in the erythrocyte series and confirmed by haemoglobin electrophoresis, rarely being found cases when haemoglobin electrophoresis with borderline values requires a molecular diagnosis. Furthermore, iron deficiency may mask the significant increase of $\mathrm{HbA} 2$ (dimorphic anemia), therefore the iron deficiency should be corrected first.

The increase in the number of cases of heterozygote subjects, favors the possibility of new cases of Cooley's anemia, a disease with profound medical and social implications.

It is necessary to continue the active work of postnatal diagnosis of $\beta$-th, even since childhood and adolescence, but also other fertile age, activity already started successfully in the three pilot counties (Dolj, Constanta, Vâlcea). A particularly important role in this activity is played by the family doctors and pediatricians, but also other categories of physicians (such as internists, etc.), a close collaboration between all the medical branches being required.

In conclusion, it would be desirable to include haemoglobin electrophoresis in the set of compulsory blood examinations for every married couple and for every female patient before marriage, as it is the case in other countries where this pathology is present.

\section{Conclusions}

Starting from 10 children diagnosed with $\beta$-th and analyzing their family tree over a period of 3-4 generations, we 
found a total of 60 subjects with $\beta$-th and 9 subjects with Cooley's anaemia.

Among the youngest studied subjects there were 18 subjects with $\beta$-th, suggesting the increasing amount of heterozygotes in the population.

\section{References}

1. Olivieri NF. Thalassaemia, Clinical Aspects and Management. Baillieres Clinic Haemathology. 1998;11:147-62.

2. Predescu C. Contribuții la studiul talasemiei în România. Doctoral thesis, Bucuresti,1986

3. Turcanu L, Serban Margit. Hematologie pediatrică. Centrala Industrială de Medicamente și Cosmetice, București, 1981, 226-228.

4. Nedelcuta Ramona. Unele aspecte privind epidemiologia și clinica sindroamelor $\beta$-talasemice la copil. Doctoral thesis, University of Medicine and Pharmacy, Craiova, 2003

5. Bacârea A, Dobreanu M, Dorcioman B, Molnar E, Bacârea V. Betatalasemia in arealul Mures. Revista Romana de Medicina de Laborator. 2005; 1(1):52-55.

6. Peng YS, Sun SC, Chen QR, Wang Q, Mo BM. A novel Mutation in $\beta$-Globin Gene of a Patient with $\beta$-thalassemia. Zhongguo Shi Yan Xue Za Zhi. 2012;20(2):398-400.

7. Aydinok Y. Thalassemia. Hematology. 2012;17(S1):S28-31.

8. Antonesei Ml. Aspecte hematologico-biochimice în $\beta$-talasemia minoră și corelarea acestora cu mutații de la nivelul genelor beta-globinei și HFE. Doctoral thesis, University of Medicine and Pharmacy, Cluj-Napoca, 2009
9. Moatter T, Kausar T, Aban M, Ghani S, Pal JA. Prenatal screening for $\beta$-thalassemia major reveals new and rare mutations in the Pakistani population. Int J Hematol. 2012;95(4):394-8. Epub 2012 Mar 4.

10. Xu LH, Fang JP, Weng WJ, Huang K, Zhang YT. Autoimmune hemolytic anemia in patients with $\beta$-thalassemia major. Pediatr Hematol Oncol. 2012;29(3):235-40.

11. Bulucea D, Nedelcuta Ramona, Bulucea Catalina. Sindroamele $\beta$-talasemice la copil, Colectia Hipocrate, 48, Ed. Aius, Craiova, 2003

12. Butoianu CE, Nicoara ST. Vademecum hematologic. Ed. Medicală, București,1973

13. Bulucea D, Frecus Corina, Nedelcuta Ramona, Bica Catalina, Constantinescu Dorina, Seicaru Doru-Adrian. Ghid de diagnostic al $\beta$-talasemiei heterozigote și profilaxia postnatală a sindroamelor $\beta$-talasemice. In: Ciofu EP, Georgescu A (eds.). Urgențe în Pediatrie. Boli Cronice în Pediatrie. Ed. Medicala Amaltea, Bucharest, 2011, 47-50.

14. Frecus Corina. Epidemiologia si clinica $\beta$-talasemiei heterozigote la copil in judetul Constanta. Doctoral thesis, University of Medicine and Pharmacy, Craiova, 2009

15. Frecus Corina, Constantinescu Dorina, Bica Catalina, Seicaru DoruAdrian, Nedelcuta Ramona, Bulucea D. Talasemia intermedia. Medicina Moderna. 2009;XVI(8):432-437.

16. Bulucea D, Gheonea C. Tratamentul actual al anemiei Cooley. Infomedica.1996, IV(9):10-15.

17. Bulucea D, Nedelcuta R, Bulucea C. Profilaxia sindroamelor $\beta$-talasemice. Medicina Moderna. 2007;XIV(1):33-38.

18. Children's Hospital \& Research Center at Oakland (2005, June 20). Thalassemia: Genetic Blood Disorder Expected To Double In Next Few Decades. ScienceDaily. Retrieved March 12, 2012, from http://www. sciencedaily.com /releases/2005/06/050620003719.htm 